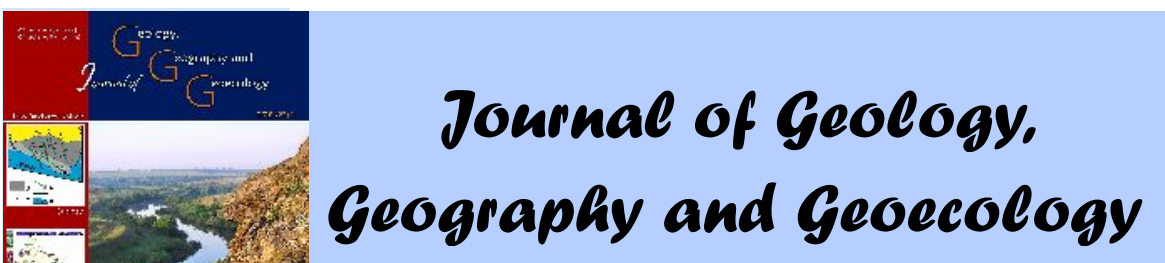

Journal home page: geology-dnu-dp.ua

Azzaoui Mohamed, Maamar Benchohra, Soudani Leila, Nouar Belgacem,

Berreyah Mohamed, MaatougMohamed

Journ.Geol.Geograph.Geoecology,27(1), 12-19

\title{
Spatial dynamics of land cover in the Sdamas region (Tiaret, Algeria)
} \author{
Berreyah Mohamed $^{3}$, MaatougMohamed ${ }^{3}$ \\ ${ }^{1}$ Ecole Supérieure d'Agronomie (ESA), Mostaganem, Algeria \\ ${ }^{2}$ El wancharissi University Center, Tissemsilt, Algeria \\ ${ }^{3}$ Ibn Khaldun University, Tiaret, Algeria \\ e-mail:moha-1500@outlook.com
}

Azzaoui Mohamed ${ }^{1}$, Maamar Benchohra ${ }^{2}$, Soudani Leila ${ }^{3}$, Nouar Belgacem ${ }^{4}$,

Received 30.04.2018;

Received in revised form 04.05.2018;

Accepted 06.06.2018

Abstract. The Sdamas massif to which our contribution relates is located in West Algeria, it is an integral part of the Tiaret mountains. The aim of our study is to analyze the land cover of the Sdamas region over a 43-year interval grouped into 9 thematic classes: mineral surfaces (urban planning), wetland, vegetation, bare soils and fallow etc. The spatial and temporal dynamics of land use require regular monitoring of vegetation cover from remote sensing imagery. It is for this reason that we relied on field data to perform the diachronic analysis with three well-defined scenes 1972, 1998 and 2015, using Landsat satellite images (MSS, TM and ETM +). The analysis of these maps covering the same region shows the different changes that have taken place at ground level. We found that our natural plant space has undergone a strong degradation, disruption and regression because of different human activities, namely: overgrazing, clearing, fires, urbanization, (there has been a remarkable increase in the population of the communes of the study area). Inadequate and ineffective forestry interventions and work, and lack of sustained protection are reasons of these processes. Factors affecting the forest ecosystem are bioclimate and human action. Indeed, the bioclimate, through atmospheric drought, is the main factor governing the diversity of these formations of the Sdamas mountains.

Key words: Dynamics, Cartography, Remote Sensing, Sdamas, Tiaret.

\section{росторов дин мік земельного покривув регіоні мм ( $\mathrm{i}$ рет, лжир)}

зз уї ох мед, м р енчхор, уд ні ейл, у р льг чеми, ерія ох мед, т уг ох мед

нот ція. сив д м с розт шов ний в хідному лжирі, він ст новить невід'ємну ч стину гірської місцевості і рет. ет н шого дослідження - н ліз земельного покриву в регіоні д м с з 43-річний період ч су, поділений н 9 тем тичних кл сів: к м'янисті поверхні (міське пл нув ння), водно-болотні угіддя, рослинний покрив, орний грунт тощо. росторов $\mathrm{i}$ ч сов дин мік землекористув ння вим г є регулярного моніторингу рослинного покриву із з стосув нням системи дист нційного зондув ння. ме з цієї причини ми спир лися н поверхневі д ні, щоб провести ді хронічний н ліз з трьом чітко визн ченими строк ми - 1972, 1998 і 2015 роки, з використ нням знімків Landsat (MSS, TM and ETM +). н ліз цих к рт, що охоплюють один і той же регіон, виявив різні зміни, які відбув ються н земній поверхні. и поб чили, що поверхня під природним з рост нням з зн л сильної дегр д ції, руйнув ння і регресії через різні види нтропогенної діяльності, с ме: н дмірний вип с худоби, утворення пустищ, пожежі, урб ніз цію (зн чний приріст н селення в $\mathrm{p}$ йоні дослідження). е декв тні і неефективні лісогоспод рські з ходи, відсутність постійної охорони є чинник ми цих процесів. инники, що вплив ють н лісові екосистеми, м ють біоклім тичне т нтропогенне походження. пр вді, біоклім т, через тмосферні посухи, являє собою основний чинник різном нітності цих утворень у гірській місцевості д м с.

лючові слов : дин мік, к ртогр фія, дист нційне зондув ння, д м с, i рет

Introduction. Detecting and characterizing change over time is the natural first step toward identifying the driver of the change and understanding the change mechanism. Satellite remote sensing has long been used as a means of detecting and classifying changes in the condition of the land surface over time (Coppin et al., 2004; Lu et al., 2004), by providing a digital scan of geographic surface (Chen et al., 
2009). Vegetation, as the main component of the terrestrial biosphere, is a crucial element in the climate system (Foley et al., 2000). a declining trend in vegetation cover is considered to be indicative of land degradation (Metternicht et al., 2010; Zika and Erb, 2009). Vegetation variability has been quantified consistently at a global scale by use of satellite remote sensing using long time-series of images with a regular acquisition interval (Justice et al., 1985).

Satellite sensors are well-suited to this task because they provide consistent and repeatable measurements at a spatial scale which is appropriate for capturing the effects of many processes that cause change, including natural e.g. longer and warmer growing seasons increase evapo-transpiration and drought stress (Barber et al., 2000; Zhang et al., 2009), wildfire incidence (Westerling et al., 2006) and anthropogenic (e.g. deforestation, urbanization, farming) disturbance (Jin and Sader, 2005).

Change detection has been firmly established through remotely sensed long term data sets (de Beurs and Henebry, 2005).

The aim of this study is to identify the spatiotemporal evolution/regression of the forest cover of Sdama mountain, Tiaret region, Algeria ,using remote sensing data derived from three scenes 1972, 1998 and 2015 associated with several inspections.

Materials and Methods. The Sdamas mountains are part of the Monts de Tiaret and cover 82000 ha, subdivided into two lots: Sdamas Chergui (44,000 ha) and Sdamas Gharbi (38,000ha) considered as old state forests (Boudy,1955). The study area in the Sdamas massif is shown in Figure 1. Block - scheme of case study is shown in Figure 2.

The data used for the realization of this work are those of the years 1972, 1998 and 2015, a 43-year observation period, freely available online. It is a series of satellite images of the Landsat satellite, namely Landsat (MSS) of November 1972 considered as the oldest image, Landsat 5 TM images acquired March 1998 and Landsat 8 OLI $(\mathrm{ETM}+)$ image of May 2015. It goes back to the spring and autumn period. This acquisition period is most suitable to the approach followed, which is essentially based on the analysis of the vegetation index influenced by the presence of the annual vegetation. A digital terrain model (DTM) is a representation of the topography in a form suitable for use by a computer. The DTM is used for the extraction of topographic parameters (slope, relief orientation (exposure, altitudes etc.) of the study area. After treatment with $\mathrm{ENVI}^{\circledR}$ and ArcGIS Software for the extraction of maps: slope, relief orientation (exposure), and treatment by the normalized vegetation difference index (NDVI). Subsequently, interpretation and analysis allow the development of soil occupation maps and then a diachronic study.

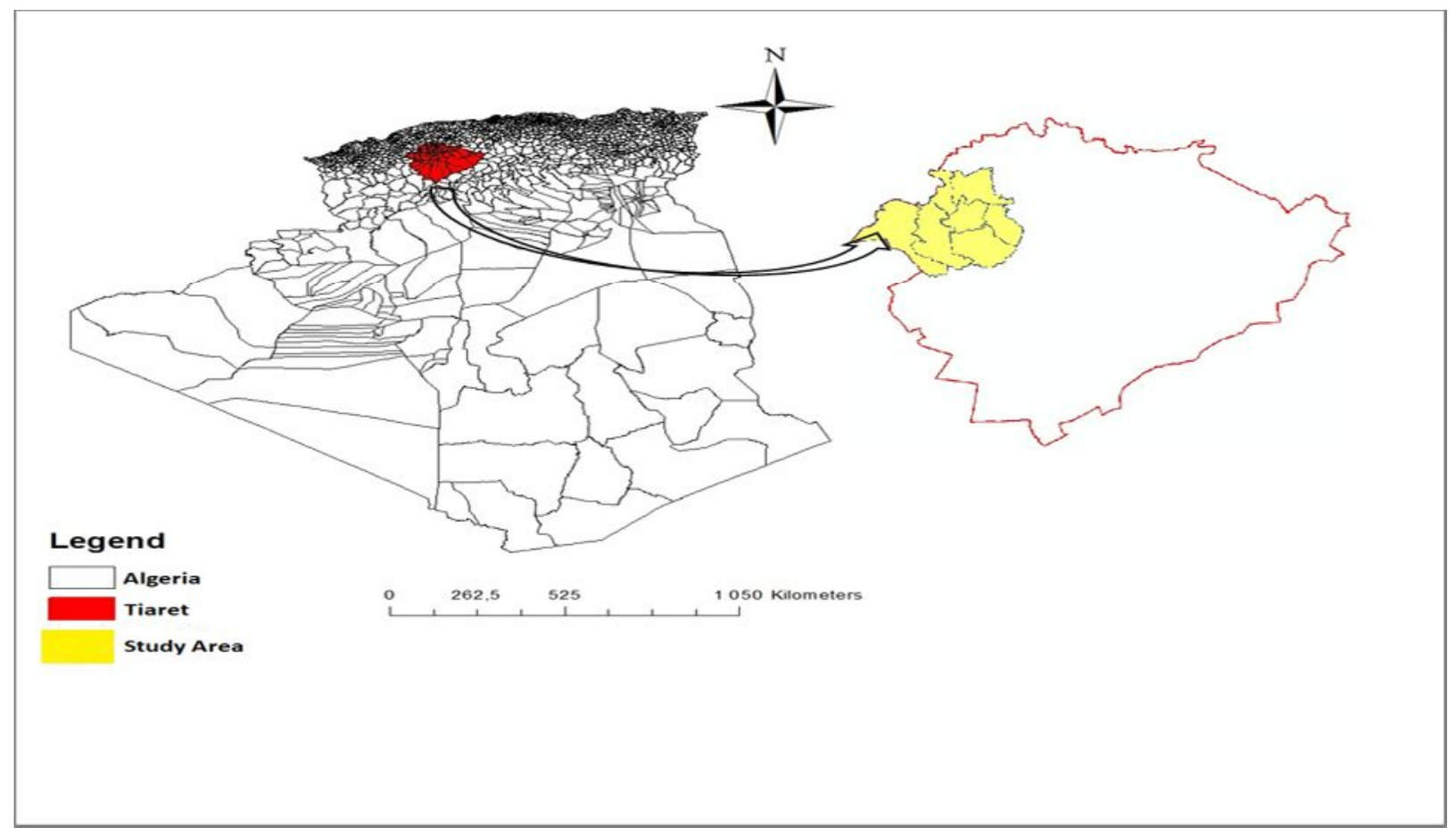

Fig. 1. Study area, Sdamas massif 


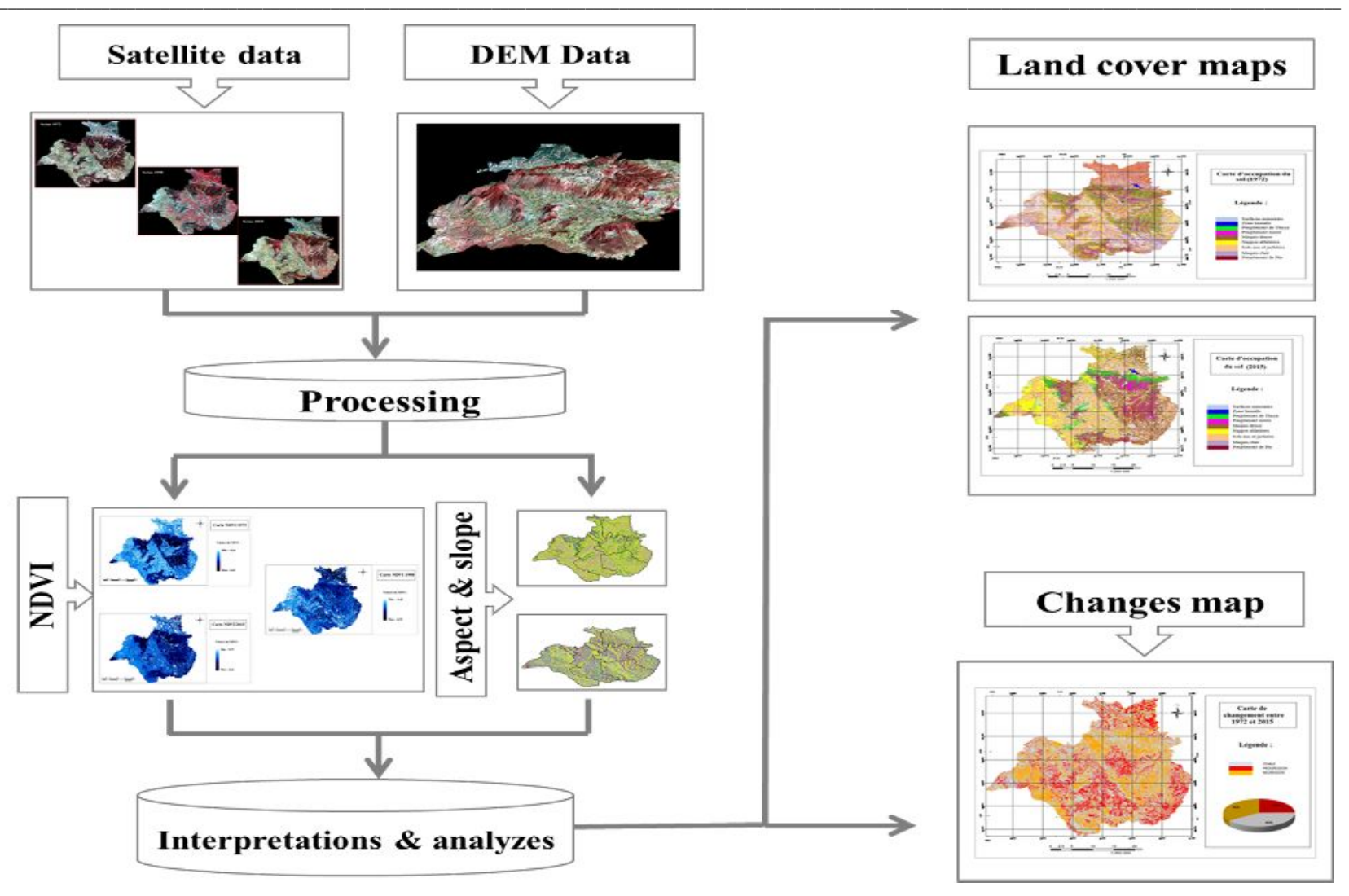

Fig. 2. Organizational methodological scheme

Results and Discussion. The results of the different thematic classes definitively retained during the classification of NDVI constitute the legend of the maps of occupation of the ground surveyed. Nine thematic classes are selected: wetland (water bodies), bare soil and fallow land with natural lawns and pastures and heterogeneous agricultural zones, as well as forest vegetation including: Tetraclinis articulata stand, mixed stand, dense maquis, clear maquis, Stipa tenacissima layers, maquis of Pinus halepensis and mineral surfaces.

The intersection of the three land use maps from 1972 to 2015 made it possible to map developments during these 43 years. The map of the changes in the land-use status was carried out to support the crossing of the two land-use maps of 1972 and 2015. This cross is made on the basis of a codification of land occupation classes. (time series). The multidated analysis is the use of data analysis methods from the channels of the three dates, or calculation of radiometric differences between two dates. The quality of the result obtained by this type of approach is highly dependent on the precision of the geometric superposition between the studied images. In fact, pixel comparison with its counterparts is mainly applied in regions where radiometry varies greatly from one point to another (Briki et al., 2007, Gacemi, 2010, Maille et al., 2011, Haddouche et al. al., 2011, Ayache, 2012, Mendas et al., 2013 and Merioua, 2014). NDVI is an index that is closely correlated with the chlorophyll activity of plant surfaces (Girard, 2000). It is determined from reflectances in the red and near infrared channels,

$$
\text { NDVI = (NIR - R }) /(\text { NIR + R }) \text {. }
$$

The NDVI highlights the presence of the chlorophyllous activity of the vegetation, where it reflects a maximum of energy captured and recorded by the satellite sensor (Benhanifia et al., 2015). The resulting NDVI maps are shown in Figure 3. The NDVI's interpretation is that healthy and active vegetation occupy high values while low values indicate absence or degradation of the plant environment. For the 1972 scene, values range from -0.16 to 0.42 . The analysis of NDVI vegetation index results indicates maximum values for dense vegetation (forest cover) consisting mainly of holm and kermes oak Quercus ilex, coccifera respectively, and are generally concentrated in the northern part of the study area. In addition, the NDVI for the year 1998 shows values ranging between -0.46 and 0.55 . due to the presence of bush-based maquis, mainly cedar and other hardwood species such as oak. As the scene was taken in March 1998, so we notice the presence of chlorophyllous activity in the north of the area due to the presence of annual crops (since the north includes farmland). NDVI values for 2015 can range from -0.35 to 0.43 . We notice a presence of forest vegetation based on softwoods and hardwoods. In the present scene acquired in May 2015, 
we can notice the disappearance of the chlorophyllous activity present in the scenes of 1998 because this period of the year is characterized by a decrease of the chlorophyllous activity for the annual plants (beginning of the harvest period). The high NDVI values 0.6 to 0.7 on average correspond to broadleaved plant formations, followed by conifers, which in turn record NDVI values of 0.4 to 0.5 . Finally, bushy vegetation is found with NDVI values ranging from 0.2 to 0.4 . These results are evidenced by the following work: Rouse et al., 1974; Baret et al., 1989; Guyot et al., 1989; Guyot, 1989; Breda et al., 2003 and Ayache et al., 2011. A supervised classification, maximum of real semblances was made to define the thematic classes by the choice of the region of interest (ROI). This detailed classification makes it possible to distinguish nine thematic classes: mineral surfaces, wetland, stand of $T$ articulata, mixed stand, dense maquis, clear maquis, $S$. tenacissima layers, bare and fallow soils, maquis of $P$. halepensis.
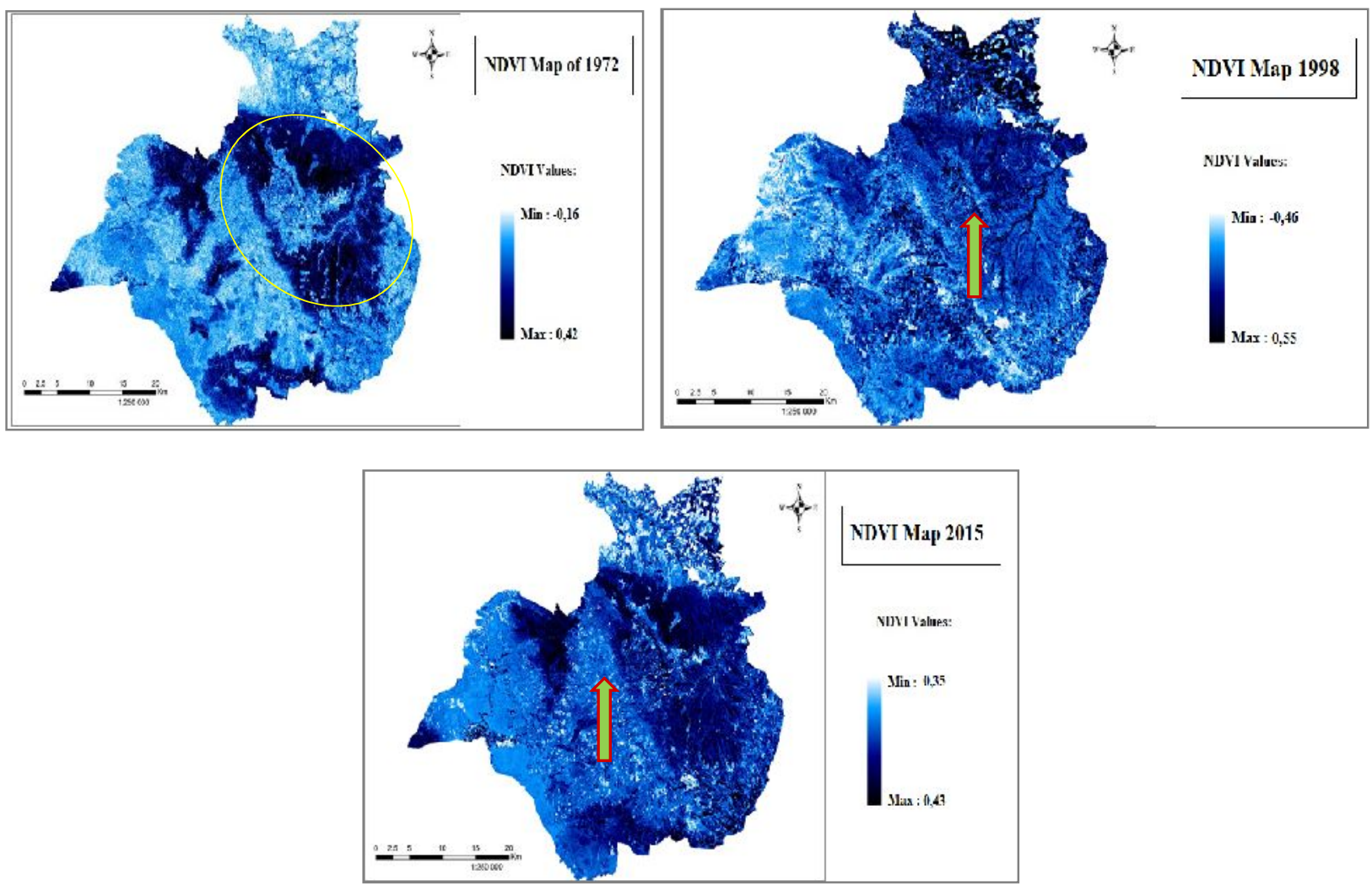

Fig. 3. Resulting NDVI maps.

Map of land occupation in 1972 year is shown in Figure 4.

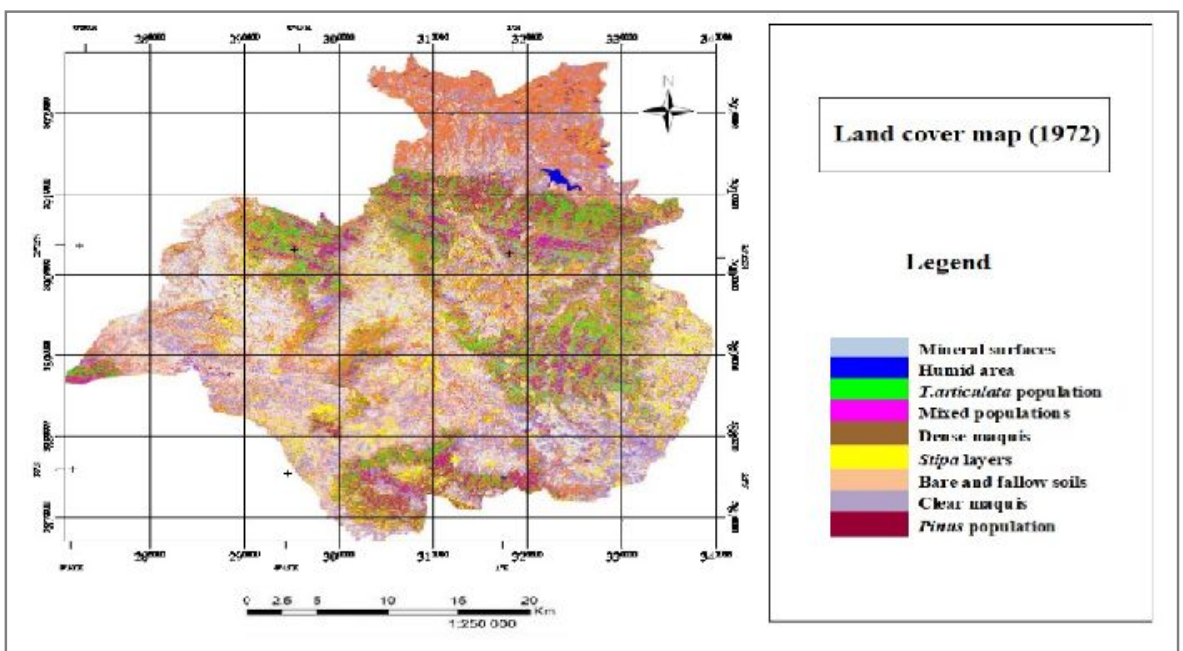

Fig. 4. Map of land occupation, 1972 
The analysis of the map shows a predominance of woodlands where clear and dense maquis are the most dominant compared to other units. In addition, bare land, cultivated land or even urban areas are in second position. The lowest proportion is that of water bodies. The predominance of these diverse forest lands includes natural forest formations such as T. articiculata forests, P. halepensis forests, dense maquis, and scrubland, as evidenced by the low pressure on forest formations and their successful adaptation to edaphoclimatic conditions during the year 1972. After classification of 1998 image (Fig.5), we observe a predominance of bare and fallow soils, this predominance is the physical indicator reflecting a fairly significant degradation that occurred at the level of the study area, followed by $P$. halepensis, light maquis and $S$. tenacissima layers. T. articulata stands and dense maquis are poorly represented in the study area.

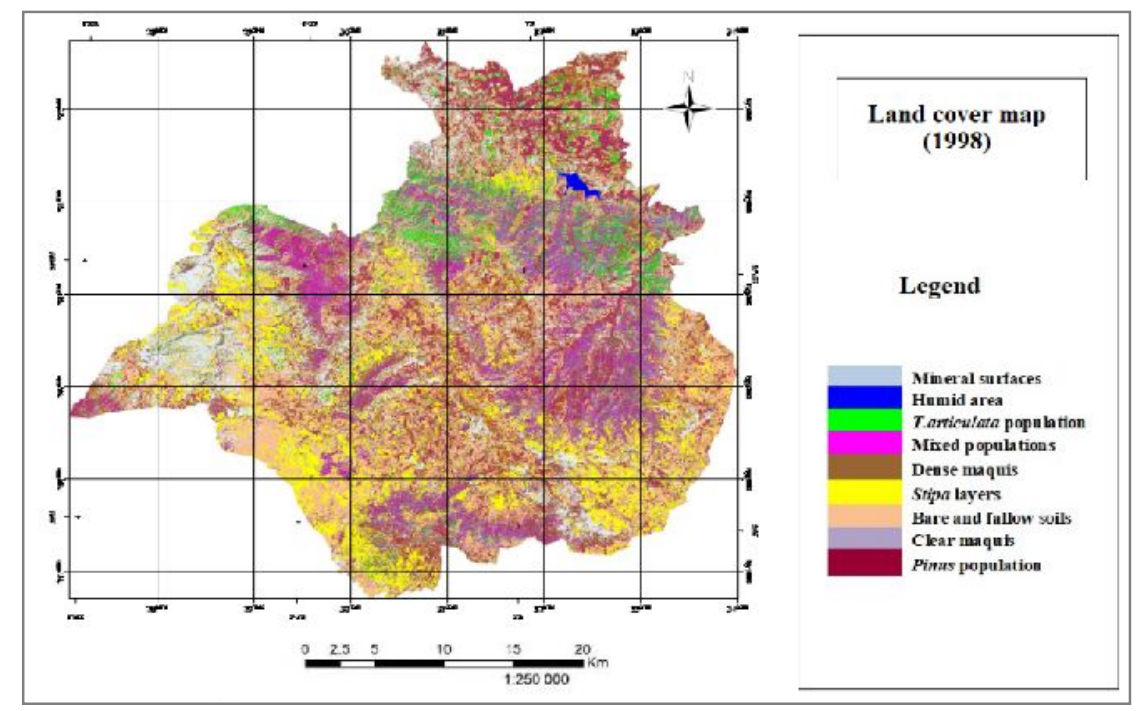

Fig. 5. Map of land occupation, 1998

The mineral surfaces (built) experienced a consequent decrease during this period, explained by the phenomenon of rural exodus due to security reasons in this region at that time. Based on the map analysis, we found that forest vegetation occupies a total of $58.77 \%$ of the total area of the study zone; degraded formations (maquis and matorrals) are the most dominant, and phytoecologically, forests of $P$. halepensis, $Q$. ilex and coccifera and T. articulata are characteristic plant formations of the forest of Sdamas. The map of land occupation in 2015 is shown in Figure 6.

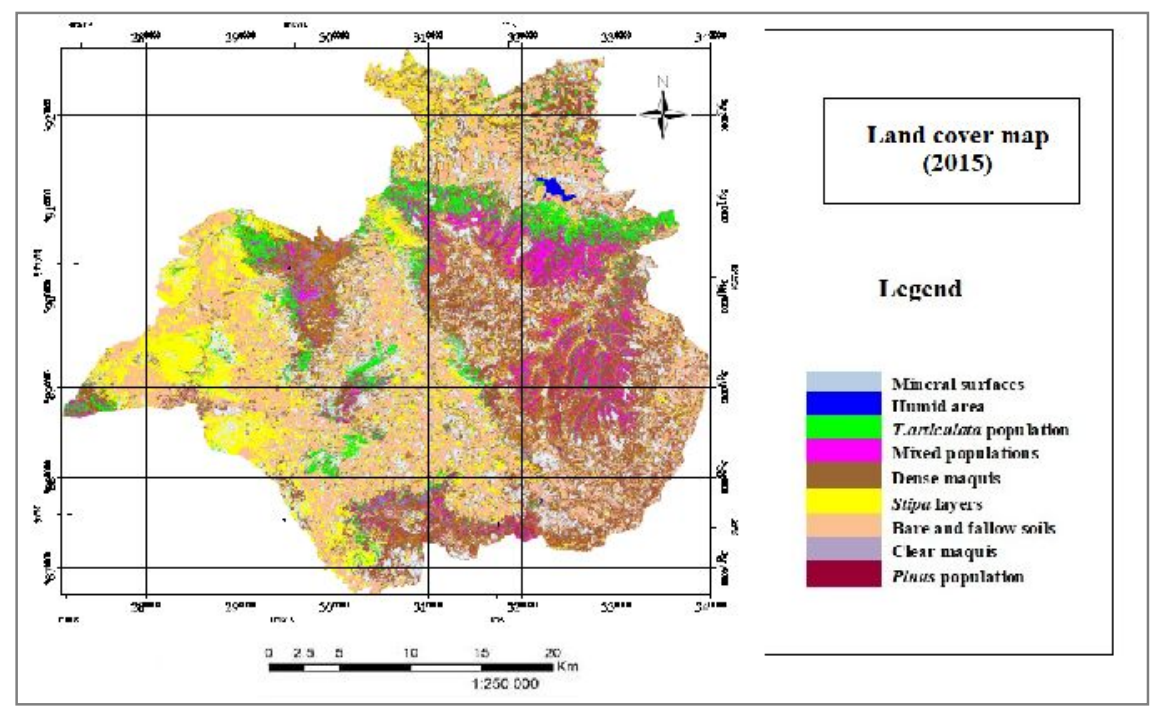

Fig. 6. Map of land occupation, 2015 
There is a clear dominance of the maquis (based on oaks and Aleppo pine) in the forest part; the $T$. articulata stand has a smaller area. This is followed by bare soil and fallow (lawns and even agricultural land) which occupies a large area with S. tenacissima layers in the south of the region scrub vegetation), which shows the state of degradation of the region. Over the past 43 years, changes in land cover can be summarized as follows: Regression of vegetation cover or Extension of vegetation cover. Diachronic Representation of Land Cover from 1972 to 2015 is shown in Figure 7. An analysis of the dynamics of changes between 1972 and 2015 reveals that $T$. articulata populations have increased markedly through the ability of this species to reject strains. There was also an extension of the class areas $P$. articulata population, mineral surface, bare soil (4.70\%) and S.tenacissima (7.49\%). However, there was a regression of the classes of clear and dense maquis with $14.49 \%$ mixed population, which is possibly explained by the repeated fires triggered since the $90 \mathrm{~s}$ and overgrazing by the local population.

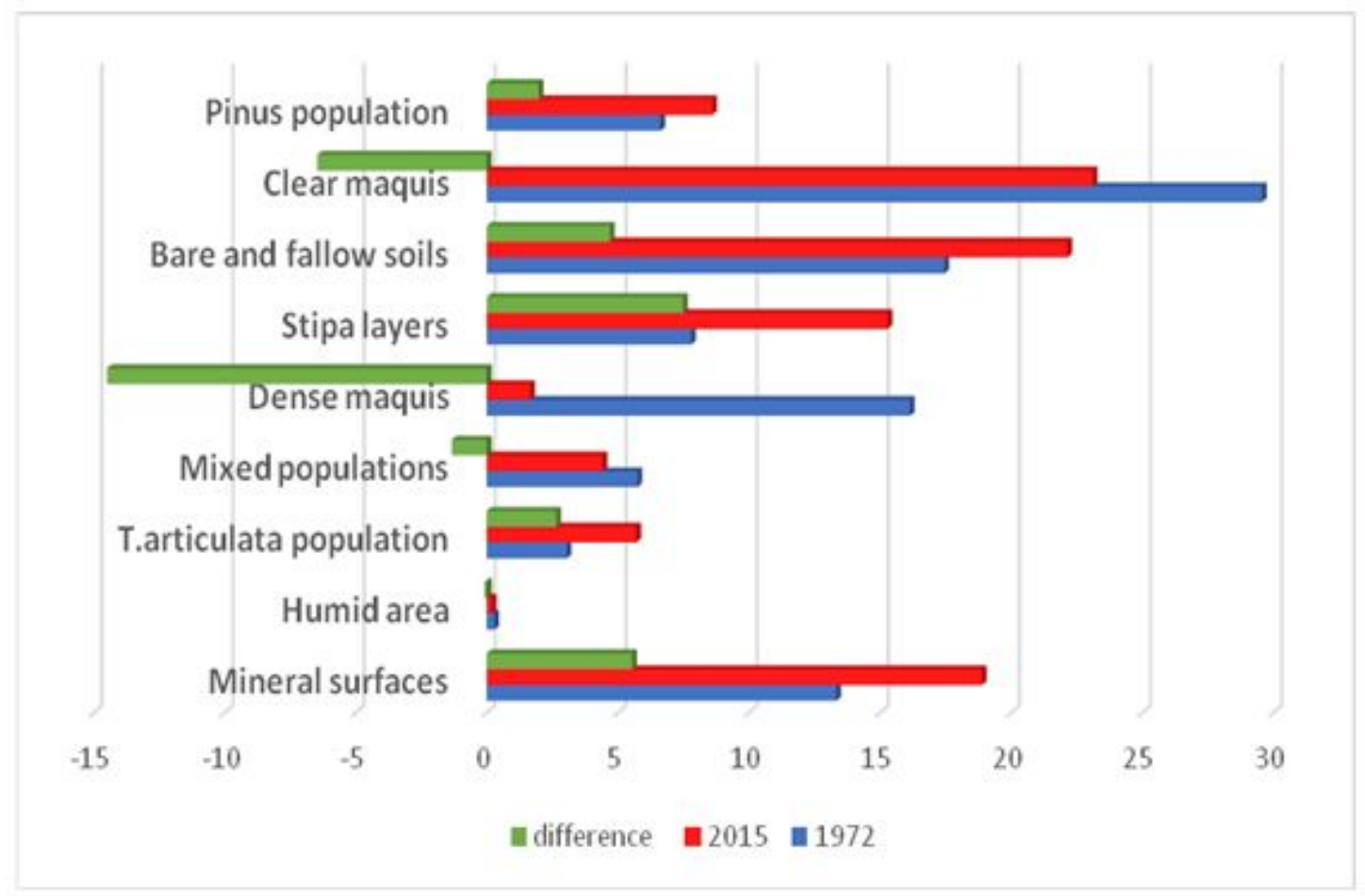

Fig. 7. Diachronic Representation of Land Cover (1972 and 2015)

The introduction of agriculture on forest land has caused irreparable damage to forest land and has promoted the degradation of dense forests and desertification due to the illegal clearing of land, overgrazing, not to mention illicit actions in the forest, especially the provocation of fires, illegal felling etc. It is , of course , perfectly well-, known that these factors can considerably increase the extent of totally degraded lands (Quezel, 2000, Benabadji and Bouazza, 2000). The map in Figure 8 indicates that $40 \%$ of the study area has not undergone any changes or modifications in structure. However, $35 \%$ suffered a regression and $25 \%$, has undergone a progression.
The map of the changes above shows perfectly visible progressions in the central part of the study area. Increases in areas classified as bare soil, agricultural land and even mineral surfaces (buildings) have increased with the extension of towns. The north-west, the mountains of Sdamas Gherbi, has experienced stability. The regression affected the eastern part mainly because it represents the greater part of the forest of Sdamas. The matorrals experienced a decline in their area. Rangelands and natural pastures also show a decline in area. 


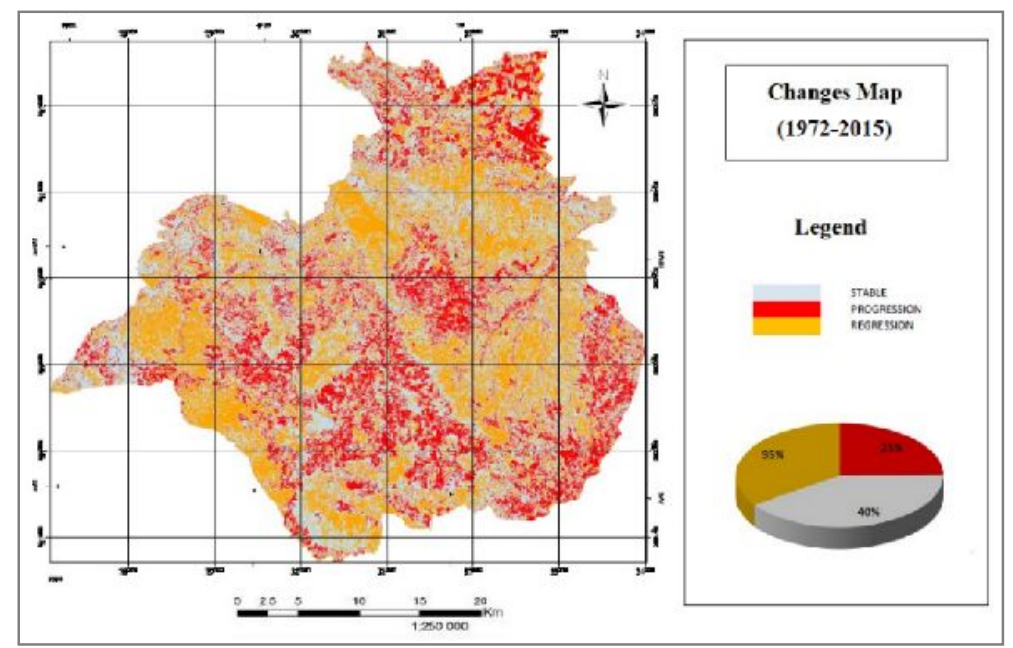

Fig. 8. Land changes map (1972-2015)

Conclusion. The aim of this study is to analyze, over a 43-year interval, the spatial dynamics of land use in the Sdamas region, grouped into 9 thematic classes according to the supervised classification, which requires knowledge of the land to be studied and subsequent on-site verification. The analysis of these maps covering the same region shows the different changes that occur at ground level. We found that our natural plant space has undergone a strong degradation, disruption and regression because of different human activities, namely: overgrazing, clearing, fires, urbanization, (a result of the remarkable increase of population in the communes of the study area). Inadequate and ineffective forestry interventions and work, and lack of sustained protection. Factors affecting the forest ecosystem are bioclimate and human action. Indeed, the bioclimate, through atmospheric drought, is the main factor governing the diversity of these formations of the Sdamas mountains.

\section{References}

Ayache, A., Ayad, N., Hellal, B., Maatoug, M. 2011. Densité et taux de recouvrement d'armoise blanche (Artemisia herba-alba Asso.) de la steppe occidentale d'Algérie. Sécheresse ; 22 (3) : 192196. doi : 10.1684/sec.2011.0308.

Ayache, A. 2012. Dynamique des peuplements d'armoise blanche (Artemisia herba-alba Asso.) de la région d'El Aricha (Algérie occidentale). PhD Thesis . Path. Ecos. Terr. Dép. scie. Env. Fac. Sci. Univ. UDL. SBA. 119.

Baret, F., Guyot, G. and Major, D. 1989. TSAVI vegetation index which minimizes soil brightness effects on LAI or APAR estimation, in 12th Canadian symposium on remote sensing and IGARSS'90, Vancouver, Canada,10-14 July.

Benabadji, N. \& Bouazza, M. 2000. Quelques modifications climatiques intervenues dans le Sud-
Ouest de l'Oranie (Algérie Occidentale). Rev. En. Ren. Vol. 3, 117-125.

Benhanifia, K., Haddouche, I., Gacemi, M.A., Bensaid, A. 2015.Etude spatiale de l'état après feu de la forêt de Fergoug (Mascara, Algérie). Les actes du Med Suber 1 : 1ère Rencontre Méditerranéenne Chercheurs- Gestionnaires-Industriels sur la Gestion des Subéraies et la Qualité du liège. Les 19 et 20 octobre 2009 - Université de Tlemcen: 67-77.

Boudy, P. 1955. Economie forestière Nord-africaine, description forestière de l'Algérie et de la Tunisie. Larose edit. Paris. T. IV, 483p.

Breda, N., Soudani, K., Bergonzini, J.C. 2003. Mesure de l'indice foliaire en forêt - Edition ECOFOR ISBN 2-914770-02-2. 157 p.

Briki, M., Benkhatra, N., Jauffret, S., Amwata, D., Requier Desjardins, M., Benhanafia, K., Hassani, M., Gacemi, M.E., 2007. Combining local observation and remote sensing for monitoring range land in arid zones "conference-Range Monitoring Expert Consultation Meeting organized by FAO, November, Cairo:. 26-28.

Gacemi, M.E., 2010.Integration of image processing methods for fuel mapping, in. Sandro Bimonte, André Miralles, François Pinet. Actes du 3ème Atelier INFORSID-SIDE (Système d'Information et de Décision pour l'Environnement). Marseille. $35 \mathrm{p}$.

Girard, M., 2000. Traitement des données de télédétection. Dunod, Paris, 529 p.

Guyot, G., 1989. Signatures spectrales des surfaces naturelles. Collection télédétection n ${ }^{\circ} 5,178 \mathrm{p}$.

Guyot, G., Guyon, D., Riom, J.,1989. Factors affecting the spectral responses of forest canopies: A review. Geocarto International, 3 : 3-17. http://dx.doi.org/10.1080/10106048909354217.

Haddouche, I., Benhanifia, K., Gacemi, M.E., 2011. Analyse Spatiale de la régénération forestière postincendie de la forêt de Fergoug à Mascara, Algérie. Bois et Forêts des tropiques, 2011 ; 307 :23-31. https://doi.org/10.19182/bft2011.307.a20478 
Maille, E., Borgniet, L., Lampin-Maillet, C., Jappiot, M., Bouillon, C., Long-Fournel, M., Morge, D., Gacemi, M. A., Sorin, D., 2011. Integration of image processing methods for fuel mapping, Stresa (Italy), 20 - 21 October, Proceedings of the 8th International EARSEL FF-SIG Workshop.

Mendas, A., Delali, A., Khalfallah, M., Likou, L., Gacemi, M. A., Boukrentach, H., Djilali, A. et Mahmoudi, R., 2013. Improvement of land suitability assessment for agriculture application in Algeria, Arabian Journal of Geosciences. DOI 10.1007/s12517-013-0860-2

Merioua, S.M. 2014. Phyto-écologie et éléments de cartographie de la couverture végétale cas : littoral d'Ain Temouchent (Algérie). PhD Thesis. Manag. Ecosy. Forest. Step. Dép. Agro.et Forest. Fac. Sci. Univ. Tlemcen. $145 \mathrm{p}+$ annexes

Quezel, P. 2000. Réflexions sur l'évolution de la flore et de la végétation au Maghreb méditerranéen. Ed. Ibis. Press. Paris : 13-117.

Rouse, J.W., Haas, R.H., Schell, J.A., Deering, D.W., et Harlan, J.C. 1974. Monitoring the vernal advancement and rétrogradation (greenwave effect) of natural vegetation. NASA/ GSFC Type III Final Report, Grennbelt, Maryland, 50.

Foley, J.A., Levis, S., Costa, M.H., Cramer, W., Pollard, D. 2000. Incorporating dynamic vegetation cover within global climate models. Ecological Applications, 10, 1620-1632. https://doi.org/10.1890/10510761(2000)010[1620:IDVCWG]2.0.CO;2

Metternicht, G., Zinck, J.A., Blanco, P.D., Del Valle, H.F. 2010. Remote sensing of land degradation: Experiences from Latin America and the Caribbean. Journal of Environmental Quality, 39, 42-61. doi:10.2134/jeq2009.0127

Zika, M., \& Erb, K.H. 2009. The global loss of net primary production resulting from human-induced soil degradation in drylands. Ecological Economics, 69, 310-318. https://doi.org/10.1016/j.ecolecon.2009.06.014

Chen, X, Yan, J F, Chen, Z, et al. 2009. A spatial geostatistical analysis of impact of land use development on groundwater resources in the Sangong Oasis Region using remote sensing imagery and data. Journal of Arid Land, 1(1): 1-8.

Justice, C.O., Townshend, J.R.G., Holben, B.N., Tucker, C.J. 1985. Analysis of the phenology of global vegetation using meteorological satellite data. International Journal of Remote Sensing, 6, 12711318. https://doi.org/10.1080/01431168508948281

Coppin, P., Jonckheere, I., Nackaerts, K., Muys, B., Lambin, E. 2004. Digital change detection methods in ecosystem monitoring: A review. International Journal of Remote Sensing, 25(9), 1565-1596. https://doi.org/10.1080/0143116031000101675

Lu, D., Mausel, P., Brondizio, E., Moran, E. 2004. Change detection techniques. International Journal of Remote Sensing, 25(12), 2365-2407. https://doi.org/10.1080/0143116031000139863

De Beurs, K. M., \& Henebry, G. M. 2005. A statistical framework for the analysis of long image time series. International Journal of Remote Sensing, 26(8),

1551-1573. https://doi.org/10.1080/01431160512331326657

Jin, S. M., \& Sader, S. A. 2005. MODIS time-series imagery for forest disturbance detection and quantification of patch size effects. Remote Sensing of Environment, 99(4), 462-470. https://doi.org/10.1016/j.rse.2005.09.017

Barber V.A., Juday G.P., Finney B.P. 2000. Reduced growth of Alaskan white spruce in the twentieth century from temperature-induced drought stress. Nature, 405, 668-673. doi:10.1038/35015049

Zhang, K., Kimball, J.S., Mu, Q., Jones, L.A., Goetz, S.J., Running, S.W. 2009. Satellite based analysis of northern ET trends and associated changes in the regional water balance from 1983 to 2005 . Journal of Hydrology, 379, 92-110. https://doi.org/10.1016/j.jhydrol.2009.09.047

Westerling, A.L., Hidalgo, H.G., Cayan, D.R., Swetnam, T.W. 2006. Warming and Earlier Spring Increase Western U.S. Forest Wildfire Activity. Science, 313, 940-943. DOI: 10.1126/science.1128834 